\title{
Tungsten-Promoted Intramolecular Annulation of Propargyl Bromides with Ketones and Aldehydes for Synthesis of F used 2,5-Dihydrofurans
}

\author{
Shwu-J u Shieh, ${ }^{\dagger}$ Tze-Chin Tang, ${ }^{\dagger}$ J ien-Shiu Lee, ${ }^{\dagger}$ Gene-Hsian Lee, ${ }^{\ddagger}$ Shie-Ming Peng, ${ }^{\ddagger}$ and \\ Rai-Shung Liu*,t
}

Department of Chemistry, National Tsinghua University, Hsinchu, 30043, Taiwan, Republic of China, and Department of Chemistry, National Taiwan University, Taipei, 10764, Taiwan, Republic of China

Received December 8, $1995^{\otimes}$

\begin{abstract}
Metal carbonyl salts $\mathrm{CpW}(\mathrm{CO})_{3} \mathrm{Na}, \mathrm{Re}(\mathrm{CO})_{5} \mathrm{Na}$, and $\mathrm{CpFe}(\mathrm{CO})_{2} \mathrm{Na}$ were used for intramolecular cyclization of 1-(3-bromo-1-propynyl)-2-(3-oxopropyl)benzene. Among these salts, $\mathrm{CpW}(\mathrm{CO})_{3} \mathrm{Na}$ was found to be the most effective in yielding a metalated fused $\eta^{1}-2,5$-dihydro-3-furyl complex. To generalize this cyclization, a number of organic substrates containing propargyl bromide and tethered aldehyde or ketone were prepared. Cyclizations of these substrates by $\mathrm{CpW}(\mathrm{CO})_{3} \mathrm{Na}$ proceeded with moderate yields (50\%-65\%), producing fused tungsten- $\eta^{1}-2,5$-dihydrofur-3-yl compounds of five, six-, and seven-membered rings. Demetalations of these organometallic products by $\left(\mathrm{NH}_{4}\right)_{2} \mathrm{Ce}\left(\mathrm{NO}_{3}\right)_{6}$ in $\mathrm{CH}_{3} \mathrm{OH} / \mathrm{CH}_{2} \mathrm{Cl}_{2}$ under flowing $\mathrm{CO}$ provided fused 3-(methoxycarbonyl)-2,5dihydrofurans; the yields were $50-60 \%$ for most cases. Consecutive oxidations of the representative $\eta^{1}$-2,5-dihydrofur-3-yl complex 15 to its fused $\eta^{1}$-2-furyl and further to $\eta^{1}$-butenolide derivative were accomplished in good yields. Demetalations of these two fused $\eta^{1}$-heterocycles were successful for $\eta^{1}$-butenolide but not for the $\eta^{1}$-2-furyl derivative.
\end{abstract}

\section{Introduction}

Metal-mediated intramolecular annulation of unsaturated carbonyl halides (or pseudohalides) with ketones and aldehydes is useful for the synthesis of complex cyclic oxygenated molecules, ${ }^{1-4}$ partially owing to the relatively easy synthesis of these organic substrates. Typically, low-valent metals initiate the reaction through oxidative displacement of halides, thereby yielding reactive organometallic anion equivalents to achieve a subsequent carbon-carbon bond-forming reaction with ketones and aldehydes. This synthetic method proceeds well with allyl $^{3}$ and vinyl halides ${ }^{4}$ (Scheme 1 , eqs 1 and 2 ) but not for propargyl halides for which the well-known allenicpropargyl equilibrium of the corresponding organometallic intermediates interferes (Seheme 1, eq 3), ${ }^{5,6} \mathrm{~A}$

\footnotetext{
† National Tsinghua University.

₹ National Taiwan University.

${ }^{\otimes}$ Abstract published in Advance ACS Abstracts, April 15, 1996.

(1) (a) Saccomano, N. A. In ComprehensiveOrganic Synthesis; Trost, B. M., Fleming, I., Schreiber, S. L., Eds.; Pergamon Press: Oxford, 1991; Vol, 1. pp 173-209. (b) Cintas, P. Synthesis 1992, 248.

(2) (a) Molander, G. A. Chem. Rev. 1992, 29-68. (b) Sosnowski, J . J.; Danaher, E. B.; Murray, R. K., J r. J . Org. Chem. 1985, 50, 2759. (c) Molander, G. A.; McKie, J. A. J . Org. Chem. 1991, 56, 4112. (d) Tabuchi, T.; I nanaga, J .; Yamaguchi, M. Tetrahedron Lett. 1986, 27, 1195. (e) Okuda, S.; Nakatsuhkasa, K.; Oshima, K.; Nozaki, H. Chem. Lett. 1985, 481. (f) Kan, T.; Nara, S.; Ito, S.; Matsuda.; Shirahama, H.
} J . Org. Chem. 1994, 59, 5111.

(3) For representative natural product syntheses involving intramolecular cyclization of allyl halides with aldehydes and ketone as the key step, see: (a) Rayner, C. M.; Astles, P. C.; Paquette, L. A. J . Am. Chem. Soc. 1992, 114, 3926. (b) Still, W. C.; Mobilio, D. J . Org. Chem. 1983, 48, 4785. (c) Shibuya, H.; Ohashi, K.; Kawashima, K.; Hori, K.; Murakami, N.; Kitagawa, I. Chem. Lett. 1986, 85. (d) Kato, N.; Tanaka, S.; Takeshita, H. Chem. Lett. 1986, 1989. (e) Wender, P. A.; McKinney, J . A.; Mukai, C. J . Am. Chem. Soc. 1990, 112, 5369.

(4) For representative product syntheses involving intramolecular cyclization of vinyl halides with aldehydes and ketone as the key step, see: (a) Corey, E. J .; Munroe, J . E. J . Am. Chem. Soc. 1982, 104, 6129. (b) Schreiber, S. L.; Meyers, H. V. J . Am. Chem. Soc. 1988, 110, 5198. (c) Aicher, T. D.; Buszek, K. R.; Fang, F. G.; Forsyth, C. J .; J ung, S. H.; Kishi, Y.; Matelich, M. C.; Scola, P. M.; Spero, D. M.; Yoon, S. K. J . Am. Chem. Soc. 1992, 114, 3162. (d) Rowly, M.; Kishi, Y. Tetrahedron Lett. 1988, 29, 4909. (e) Sakae, A.; Wang, T. C.; Kibayashi, C. J . Am. Chem. Soc. 1993, 115, 11393. (f) I Isono, N.; Mori, M. J. Org. Chem. 1995, 60, 115.
(1)

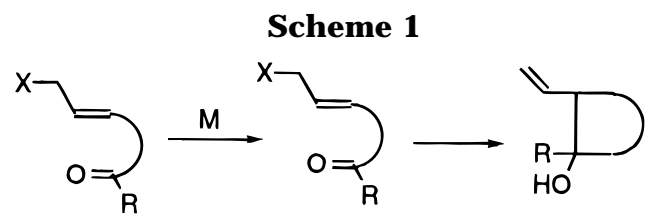

(2)

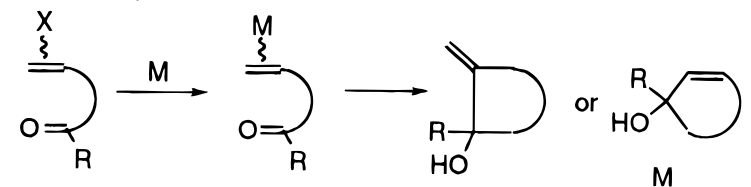

(3)
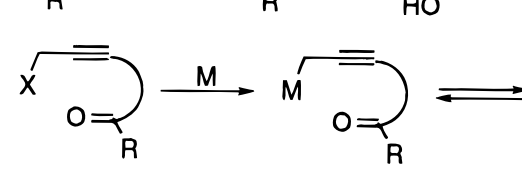<smiles>[M]C(=C)CCC([R])=O</smiles>

recent investigation ${ }^{7}$ indicated that $\mathrm{Pd}(0)-\mathrm{Sml}_{2}$ allows the intramolecular coupling of propargyl acetate with a ketone to yield $\alpha$-alkynylcycloal kanol smoothly; however, the coupling with aldehydes is unsatisfactory $(<20 \%)$. No effective method is yet available to cyclize these substrates chemoselectively. Selective syntheses of these alcohols can be accomplished by the intramolecular coupling of allenyl- or alkynylsilane with tethered ketones and al dehydes 8,9 even though the synthesis of these silyl substrates requires extra work.

Our previous work demonstrated that in the presence of Lewis acid $\mathrm{CpW}(\mathrm{CO})_{3} \mathrm{Na}$ promoted the intermolecular

(5) (a) Yamamoto, H. In ComprehensiveOrganic Synthesis: Addition to $C-X \pi$ Bonds Part II; Trost, B. M., Fleming, I., Eds.; Pergamon Press: Oxford, 1991; Vol. 2, Chapter 1.3, p 81. (b) Panek, J. S. In Comprehensive Organic Synthesis: Addition to $C-X \pi$ Bonds Part II; Trost, B. M., Fleming, I., Eds.; Pergamon Press: Oxford, 1991; Chapter $2.5, \mathrm{p} 580$.

(6) (a) Imai, T.; Nishida, S. J . Chem. Soc., Chem. Commun. 1994, 277. (b) Place, P.; Verniere, C.; Gore, J . Tetrahedron 1991, 37, 1359. (c) Rozema, M. J .; Knochel, P. Tetrahedron Lett. 1991, 1855.

(7) Aurrewechea, J . M.; Anton, R. F. S. J . Org. Chem. 1994, 59, 702.

(8) (a) Marshall, J . A.; Wang, X.-j. J . Org. Chem. 1992, 57, 3387. (b) Marshall, J. A.; Wang, X.-j. J . Org. Chem. 1991, 56, 6264.

(9) (a) Borzilleri, R. M.; Weinreb, S. M. J . Am. Chem. Soc. 1994, 116, 9789. (b) Tius, M.; Culligham, J. M. Tetrahedron Lett. 1898, 30, 3749. 
$[3+2]$ cycloaddition of propargyl halides with aldehydes, yielding $\eta^{1}$-2,5-dihydrofuryl compounds ${ }^{10,11}$ in excellent yields (85-90\%); the intermediate was a tungsten $\eta^{1-}$ propargyl species that could be isolated. In this case, the formation of 2,5-dihydrofuran products is unprecedented in the chemistry of metal propargyl and allenyl complexes. $5,12,13$ The cycloaddition, however, fails to proceed with ketones. We now extend this methodology to an intramolecular system to yield fused 2,5-dihydrofurans of various types. Moreover, the cyclization applies to both aldehydes and ketones.

\section{Results and Discussion}

Similar to $\mathrm{CpW}(\mathrm{CO})_{3} \mathrm{Na}^{14}{ }^{14} \mathrm{Re}(\mathrm{CO})_{5} \mathrm{Na}$ and $\mathrm{CpFe}$ $(\mathrm{CO})_{2} \mathrm{Na}$ in conjunction with $\mathrm{BF}_{3}$ promoted [3+2] cycloaddition of propargyl bromide to aldehydes to give metalated $\eta^{1}$-2,5-dihydrofur-3-yl compounds in ca. 80 and $50 \%$ yields, respectively. In an earlier report, ${ }^{15}$ these three anions were found to be reactive toward al dehydes. Hence, the key feature to utilize these anions for successful intramolecular annulation relies heavily on their kinetic differentiations toward these two functionalities. The prerequisite is that the anion should react more rapidly with the propargyl halides. ${ }^{9}$ We first examined the cyclization of the substrates $\mathbf{1 a}, \mathbf{b}^{16}$ with these metal anions; Scheme 2 summarizes the results. To achieve the maximum effect of kinetic differentiation, a THF solution of metal anion was slowly added to $\mathbf{1}$ in THF at $0{ }^{\circ} \mathrm{C}$. The addition was carried out in three portions with a 30-min interval. Monitoring the solution by silica TLC plate showed the formation of a tungsten- $-\eta^{1}$-propargyl complex ${ }^{17}$ that was extracted with diethyl ether and subsequently treated with $\mathrm{BF}_{3} \cdot \mathrm{Et}_{2} \mathrm{O}(0.50$ equiv) at -40 ${ }^{\circ} \mathrm{C}$. After $3 \mathrm{~h}$, the solution was gradually warmed to 23

(10) (a) Wang, S.-H.; Shiu, L.-H.; Shu, H.-G.; Liao, Y.-L.; Wang, S.L.; Lee, G.-H.; Peng, S.-M.; Liu, R.-S. J. Am. Chem. Soc. 1994, 116, 5967. (b) Shu, H.-G.; Shiu, L.-H.; Wang, S.-H.; Wang, S.-L.; Lee, G.H.; Peng, S.-M.; Liu, R.-S. J . Am. Chem. Soc. 1996, 118, 530.

(11) Shiu, L.-H.; Lee, G.-H.; Peng, S.-M.; Liu, R.-S. Unpublished results.

(12) For the application of metal-allenyl and propargyl compounds in organic synthesis, see the representative review papers in ref 5 and: (a) Fleming, I. In Comprehensive Organic Synthesis: Addition to $\mathrm{C}-\mathrm{X} \mathrm{p}$ Bonds, Part I; Trost, B. M., Fleming, I., Eds.; Pergamon Press: Oxford, 1991; Vol. 2, Chapter 2.2, p 575. (b) Epsztein, R. In Comprehensive Carbanion Chemistry; Buncel, E., Durst, T., Eds.; Elsevier: Amsterdam, 1984; Part B, p 107.

(13) For main group metal allenyl and propargyl compounds, see: (a) Seyferth, D.; Son, D. Y.; Shah S. Organometallics 1994, 13, 2105. (b) Brown, H. C. ; Khire, U. R.; Racherla, U. S. Tetrahedron Lett. 1993, 34, 15. (c) Brown, H. C.; Khire, U. R.; Narla, G.; Racherla, U. S. J. Org. Chem. 1995, 60, 544. (d) Danheiser, R. L.; Carini, D. J . J . Org. Chem. 1980, 45, 3925. (e) Boaretto, A.; Marton, D.; Tagliavini, G. J . Organomet. Chem. 1985, 297, 149. (f) Marshall J. A.; Wang, X.-J .J . Org. Chem. 1991, 56, 3212. (g) Marshall, J . A.; Wang, X. J. J . Org. Chem. 1991, 56, 6264.

(14) In this work, $\mathrm{CpW}(\mathrm{CO})_{3} \mathrm{Na}$ was prepared on heating a mixture of $\mathrm{W}(\mathrm{CO})_{6}$ and $\mathrm{NaC}_{5} \mathrm{H}_{5}$ in $\mathrm{THF}$ for $72-84 \mathrm{~h}$. It was also prepared by reduction of pure $\mathrm{Cp}_{2} \mathrm{~W}_{2}(\mathrm{CO})_{6}$ with $\mathrm{Na} / \mathrm{Hg}$ in THF . In this case, $\mathrm{Cp}_{2} \mathrm{~W}_{2-}$ $(\mathrm{CO})_{6}$ should be free of the contamination with $\mathrm{W}(\mathrm{CO})_{6} . \mathrm{Cp}_{2} \mathrm{~W}_{2}(\mathrm{CO})_{6}$ is commercially available from Strem or Aldrich. Removal of W(CO) from $\mathrm{Cp}_{2} \mathrm{~W}_{2}(\mathrm{CO})_{6}$ is achieved in high vacuum $\left(0.1 \mathrm{~Pa}, 50{ }^{\circ} \mathrm{C}, 48 \mathrm{~h}\right)$.

(15) Vargas, R. M.; Theys, R. D.; Hossain, M. M. J . Am. Chem. Soc. 1992, 114, 777 .

(16) Ciufolini, M. A.; Browne, M. E. Tetrahedron Lett. 1987, 28, 171.

(17) In this study, we have characterized several tungsten $-\eta^{1-}$ propargyl complexes 36-39 (yields $>80 \%$ ). Here, we did not find any trace of tungsten $-\eta^{1}$-allenyl compounds to support a propargyl-allenyl equilibrium. Syntheses and spectral data of 36-39 are given in the supporting information.

$$
\begin{aligned}
& w^{r} \equiv-<_{\left(\mathrm{CH}_{2}\right)_{n} \mathrm{CHO}} \quad \mathrm{w} \equiv-\left(\mathrm{CH}_{2}\right)_{\mathrm{n}} \mathrm{COMe} \\
& W=\mathrm{CpW}(\mathrm{CO})_{3}, n=2(36), n=3(37) . \quad n=2(38), n=3(39) .
\end{aligned}
$$

Scheme 2

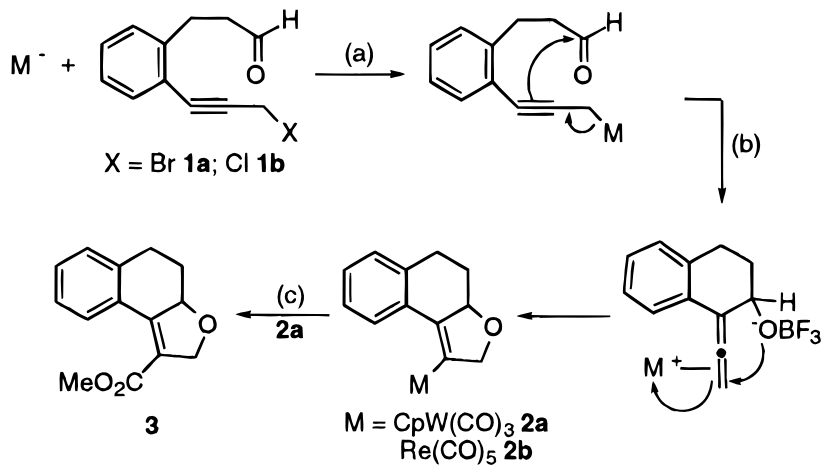

\begin{tabular}{ccccc}
\hline Entry & $\mathrm{X}$ & $\mathrm{M}$ & $\mathrm{X} / \mathrm{M}$ (molar ratio) & products (yields) \\
\hline 1 & $\mathrm{Br}$ & $\mathrm{CpW}(\mathrm{CO})_{3}$ & 1.0 & $\mathbf{2 a}(57 \%)$ \\
2 & $\mathrm{Br}$ & $\mathrm{CpW}(\mathrm{CO})_{3}$ & 0.5 & $\mathbf{2 a}(5 \%)$ \\
3 & $\mathrm{Cl}$ & $\mathrm{CpW}(\mathrm{CO})_{3}$ & 1.0 & $\mathbf{2 a}(35 \%)$ \\
4 & $\mathrm{Br}$ & $\operatorname{Re}(\mathrm{CO})_{5}$ & 1.0 & $\mathbf{2 b}(25 \%)$ \\
5 & $\mathrm{Br}$ & $\mathrm{CpFe}(\mathrm{CO})_{2}$ & 1.0 & -
\end{tabular}

(a) $0{ }^{\circ} \mathrm{C}$, THF, $3 \mathrm{~h}$, (b) $\mathrm{BF}_{3} \cdot \mathrm{Et}_{2} \mathrm{O}$ (0.5 equiv), $-40{ }^{\circ} \mathrm{C}$ to $0{ }^{\circ} \mathrm{C}, 5 \mathrm{~h}$ (c) $\left(\mathrm{NH}_{4}\right)_{2} \mathrm{Ce}\left(\mathrm{NO}_{3}\right)_{6}$ (3.0 equiv), $\mathrm{CO}(1 \mathrm{~atm}), \mathrm{CH}_{2} \mathrm{Cl}_{2} / \mathrm{CH}_{3} \mathrm{OH},-78^{\circ} \mathrm{C}, 2 \mathrm{~h} ;-78$ ${ }^{\circ} \mathrm{C}$ to $23^{\circ} \mathrm{C}, 5 \mathrm{~h}$.

${ }^{\circ} \mathrm{C}$ and quenched with aqueous $\mathrm{NaHCO}_{3}$ solution. After chromatography, the organometallic products $\mathbf{2 a}, \mathbf{b}$ (entries $1-5$, Scheme 2) were shown to be bicyclic $\eta^{1-2,5-}$ dihydro-3-furyl complexes based on spectral data and elemental analysis. Scheme 2 shows the pathway leading to $\mathbf{2 a}$, $\mathbf{b}$ through an allene cationic species. If 2 equiv of $\mathrm{CpW}(\mathrm{CO})_{3} \mathrm{Na}$ are used, the yields decrease drastically from $57 \%$ to $5 \%$. Such a decrease implies that the anion reacts irreversibly with both propargyl halides and aldehydes. As expected, propargyl bromide (1a) is superior to its chloride analogue (1b) with a significant difference in the yields (entries 1 and 3, Scheme 2). In addition, $\mathrm{CpW}(\mathrm{CO})_{3} \mathrm{Na}$ was more effective than the other two anions (entries 4 and 5, Scheme 2); $\mathrm{CpFe}(\mathrm{CO})_{2} \mathrm{Na}$ failed to give the corresponding $\eta^{1}$-propargyl species as monitored by TLC and ${ }^{1} \mathrm{H}$ NMR spectroscopy even if 1 equiv of iron anion was used. An important feature of the tungsten case is the lack of allenic-propargyl equilibrium ${ }^{17,18}$ that avoids the formation of byproducts like $\eta^{1}$-2,3-dihydro-4-furyl or $\alpha$-alkynylcycloalkanol compounds. Oxidative demetalation of $2 \mathrm{a}$ with $\left(\mathrm{NH}_{4}\right) \mathrm{Ce}\left(\mathrm{NO}_{3}\right)_{6}$ in $\mathrm{CH}_{3} \mathrm{OH} / \mathrm{CH}_{2} \mathrm{Cl}_{2}$ under flowing $\mathrm{CO}$ gas afforded 3-(methoxycarbonyl)-2,5-dihydrofuran 3 in $46 \%$ yield.

To expand the scope of cyclization, we have synthesized various organic substrates listed in Table 1 , some of which are known in literature. ${ }^{16,19}$ The remaining compounds are not difficult to prepare; the synthetic schemes and spectral data are listed in the supporting information. The substrates $\mathbf{4 - 1 0}$ (entries 1-7, Table 1) were used for the intramolecular cyclization of propargyl halides with aldehydes, whereas 11-13 were employed for the cyclizations with the tethered ketones (entries 8-10, Table 1). Experimental procedures for the cyclization reactions followed exactly those of $\mathbf{2 a}$ involving the use of equilmolar proportions of $\mathrm{CpW}(\mathrm{CO})_{3} \mathrm{Na}$ and organic substrates. In most cases, the resulting tungsten

(18) Bell, P. B.; Wojcicki, A. Inorg. Chem. 1981, 20, 1585

(19) (a) Haynes, R. K.; Lambert, D. E.; Parafiniuk, K. A.; Schober, P. A.; Turner, S. G. Aust. J. Chem. 1987, 40, 273. (b) Cossy, J .; Pete, J. P. Tetrahedron Lett. 1986, 27, 573. 
Table 1. Reaction Scheme and Isolated Yields of Tungsten- $\eta^{1}-2,5$-Dihydrofuryl Complexes and F used 3-(Methoxycarbonyl)-2,5-dihydrofurans

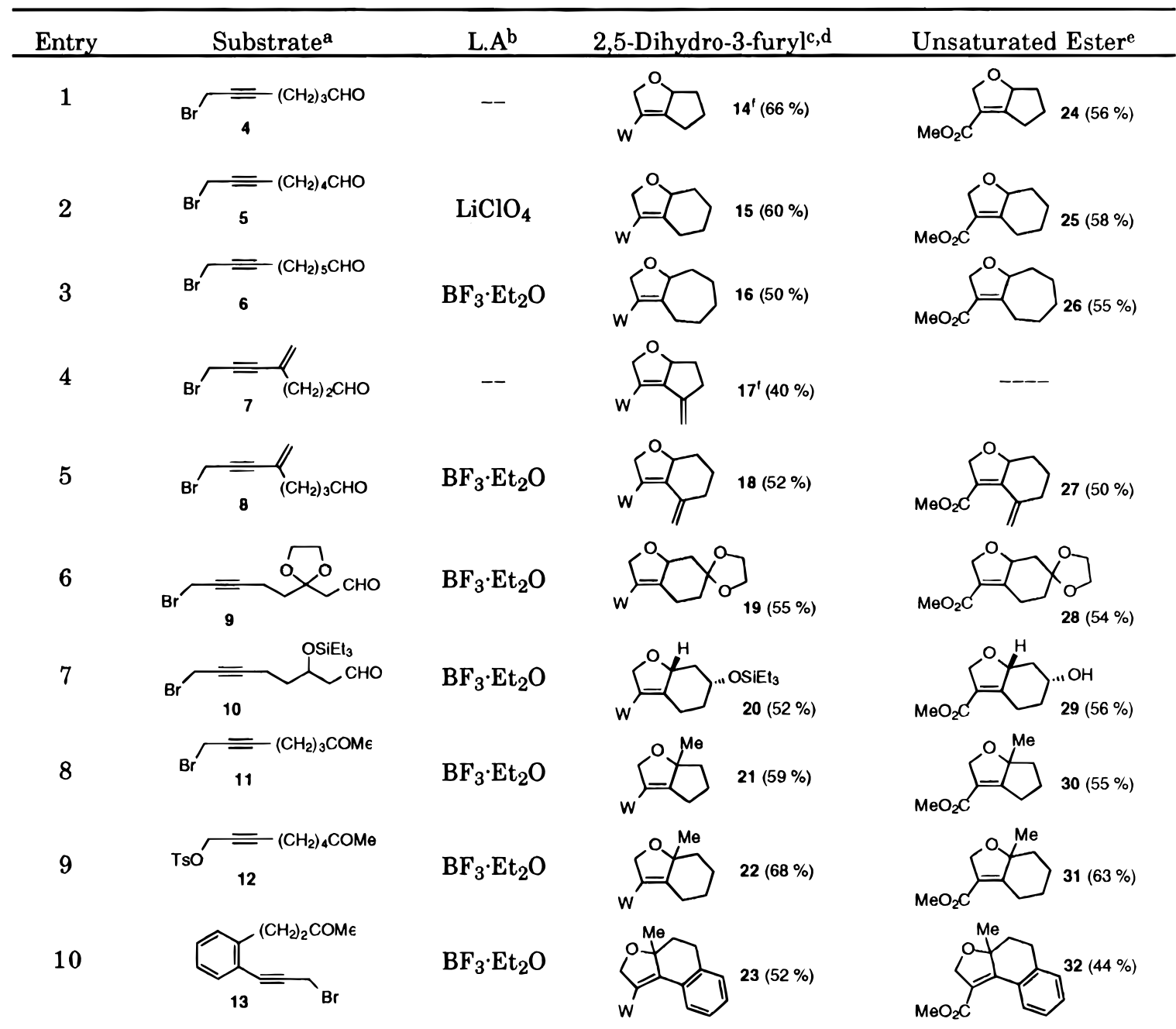

\footnotetext{
a Equimolar ratios of $\mathrm{CpW}(\mathrm{CO}) 3 \mathrm{Na}$ and organic substrates were used. b Lewis acid in equimolar proportions was used. ${ }^{\mathrm{c}}$ These organometallic compounds were purified on a silica col umn except $\mathbf{1 4}$ and $\mathbf{1 7 .} .^{\mathrm{f}} \mathrm{d}$ I solated yields after chromatographic purification. ${ }^{\mathrm{e}}$ I solated yields after purification by preparative silica TLC. ${ }^{f}$ Compounds $\mathbf{1 4}$ and $\mathbf{1 7}$ were purified on a Florisil column at $0{ }^{\circ} \mathrm{C}$.
}

$\eta^{1}$-propargyl compounds ${ }^{17}$ were subsequently treated with a suitable Lewis acid such as $\mathrm{BF}_{3} \cdot \mathrm{Et}_{2} \mathrm{O}$ or $\mathrm{LiClO}_{4}$. The yields of $\eta^{1}$-2,5-dihydro-3-furyl compounds 14-23 are shown in Table 1 . The tungsten $\eta^{1}$-heterocycles were decomplexed with $\left(\mathrm{NH}_{4}\right)_{2} \mathrm{Ce}\left(\mathrm{NO}_{3}\right)_{6}{ }^{20}$ in $\mathrm{CH}_{3} \mathrm{OH} / \mathrm{CH}_{2} \mathrm{Cl}_{2}$ under flowing $\mathrm{CO}$ ( 1 atm) to afford the bicyclic unsaturated esters 24-32 in the yields shown in Table 1. No Lewis acid was required for the annulation of fivemembered rings such as 14 and 17 (entries 1 and 4, Table 1) whereas $\mathrm{LiClO}_{4}$ was sufficiently acidic to effect the cyclization yielding 15 (entry 2, Table 1) in 60\% yield. Most of the fused $\eta^{1-2,5}$-hydrofur-3-yl compounds in Table 1 were purified by chromatography through a silica column. The exceptions were $\mathbf{1 4}$ and $\mathbf{1 7}$ that were chromatographed through a short Florisil column at 0 ${ }^{\circ} \mathrm{C}$. Entries 1-3 are fused unfunctionalized 2,5-dihydrofurans of five- to seven-membered rings. The molecular structures of $\mathbf{1 5}$ and $\mathbf{1 6}$ have been determined by X-ray diffraction studies. ${ }^{21}$ The cyclization was extended to functionalized substrates 7-10 (entries 4-9, Table 1). Entries 4-5 (Table 1) show fused dihydrofurans containing an external $=\mathrm{CH}_{2}$ bond that increases the ring strain. Consequently, the five-membered ring product 17 was

(20) Magnuson, R. H.; Meirowitz, R.; Zulu, S.; Giering, W. P. J . Am. Chem. Soc. 1982, 104, 5790. slightly thermally unstable at $23^{\circ} \mathrm{C}$, and the yiel d is low (40\%). Oxidative demetalation of 17 by $\left(\mathrm{NH}_{4}\right)_{2} \mathrm{Ce}\left(\mathrm{NO}_{3}\right)_{6}$ in the $\mathrm{CH}_{3} \mathrm{OH} / \mathrm{CH}_{2} \mathrm{Cl}_{2} / \mathrm{CO}$ system failed to produce the corresponding 3-(methoxycarbonyl)-2,5-dihydrofuran. The annulation reactions on $\mathbf{9}$ and $\mathbf{1 0}$ were examined to study the effect of a bulky substituent; the yields of the resulting products $\mathbf{1 9}$ and $\mathbf{2 0}$ were $55 \%$ and 52\%, respectively. Notably, only a single diastereomer was found for $\mathbf{2 0}$ of which the cis-configuration was indicated by proton NOE difference spectroscopy. In this case, irradiation of the $C_{9}$ proton signal ( $\left.\delta 4.80 \mathrm{ppm}\right)$ of $\mathbf{2 0}$ led to an increase of the $C_{7}$ proton intensity ( $\left.\delta 4.18 \mathrm{ppm}\right)$ by $4.5 \%$. $\mathrm{Ce}(\mathrm{IV})$ oxidation of 20 in the $\mathrm{CH}_{3} \mathrm{OH} / \mathrm{CH}_{2} \mathrm{Cl}_{2} / \mathrm{CO}$ system led to desilylation to give $\mathbf{2 9}$ in $56 \%$ yield. Although tungsten- $-\eta^{1}$-propargyl compounds failed to react with ketones intermolecularly, ${ }^{10}$ the intramolecular annulation of 11-13 proceeded smoothly yielding $\eta^{1}$ dihydrofuryl compounds of five and six-membered rings such as 21-23 in 52-68\% yields (entries 8-10, Table 1). Likewise, Ce(IV)-oxidative demetalations of $\mathbf{2 1 - 2 3}$

(21) Crystal data of 15, 16, and 34 including ORTEP drawing, atomic coordinates, bond lengths and angles, and thermal parameters have been deposited at the Cambridge Crystallographic Data Centre. The coordinates can be obtained, on request, from the Director, Cambridge Crystallographic Data Centre, 12 Union Road, Cambridge, CB2 1EZ, UK. 


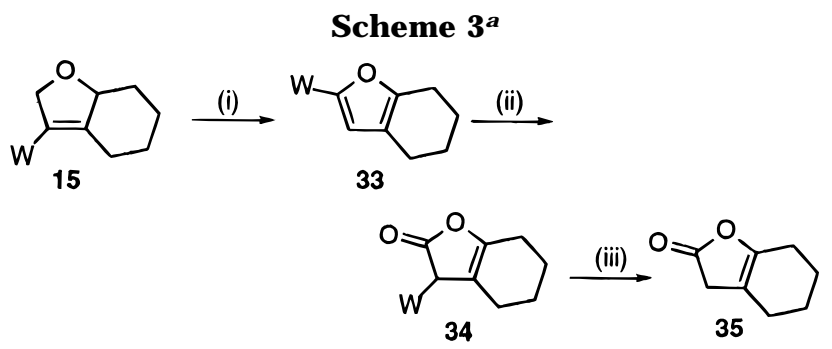

a Key: $W=\mathrm{CpW}(\mathrm{CO})_{3}$; (i) $\mathrm{Ph}_{3} \mathrm{CBF}_{4}$ (1.5 equiv, $\mathrm{CH}_{2} \mathrm{Cl}_{2}, 0^{\circ} \mathrm{C}, 1$ h); (ii) $\mathrm{NaHCO}_{3} \mathrm{~m}-\mathrm{CPBA}$ (1.2 equiv, $0{ }^{\circ} \mathrm{C}, 1.5 \mathrm{~h}$ ), $\mathrm{NaOAc} / \mathrm{HOAC}$; (iii) $\mathrm{Me}_{3} \mathrm{NO} \cdot \mathrm{H}_{2} \mathrm{O}$ (3.0 equiv, $23^{\circ} \mathrm{C}, 2 \mathrm{~h}$ ).

further provided bicyclic unsaturated ester 30-32 in 44$63 \%$ yields.

Our previous work ${ }^{10}$ demonstrated that the tungsten$\eta^{1}$-2,5-dihydro-3-furyl complex can be oxidized to $\eta^{1}$-furyl and further to $\Delta^{3}$-butenolide derivatives. Extending these oxidations to fused $\eta^{1}$-2,5-dihydro-3-furyl compounds is of interest. Treatment of $\mathbf{1 5}$ with $\mathrm{Ph}_{3} \mathrm{CBF}_{4}(1.5$ equiv) in $\mathrm{CH}_{2} \mathrm{Cl}_{2}\left(0{ }^{\circ} \mathrm{C}, 1.0 \mathrm{~h}\right)$ and then quenching with $\mathrm{NaHCO}_{3}(\mathrm{aq})$ delivered 33 in $83 \%$ yield (Scheme 3). ${ }^{10}$ The conversion of $\mathbf{1 5}$ to 33 represents an oxidative rearrangement of a $\eta^{1}$-2,5-dihydro-3-furyl to $\eta^{1}$-2-furyl derivative, of which the mechanism has been elucidated previously. ${ }^{10 \mathrm{~b}}$ Subsequent oxidation of $\mathbf{3 3}$ with $\mathrm{m}$-CPBA (2.0 equiv, 0 ${ }^{\circ} \mathrm{C}$ ) in hexane with a $\mathrm{NaOAc} / \mathrm{HOAc}$ buffer gave fused $\Delta^{3}$ butenolides $\mathbf{3 4}$ in $\mathbf{7 3} \%$ yield. Further demetalation of $\mathbf{3 4}$ with $\mathrm{Me}_{3} \mathrm{NO} \cdot \mathrm{H}_{2} \mathrm{O}$ (3.0 equiv) produced 35 in $75 \%$ yield. The molecular structure of $\mathbf{3 4}$ was determined from an $x$-ray diffraction study. ${ }^{21}$ Unfortunately, we could not decomplex 33 with various oxidants including $\mathrm{Ce}(\mathrm{IV}), \mathrm{I}_{2}$, and $\mathrm{m}$-CPBA to liberate one major furan. I nstead, a mixture of several organic products was produced.

In conclusion, we have demonstrated the use of CpW$(\mathrm{CO})_{3} \mathrm{Na}$ for intramolecular cyclization of propargyl bromides with tethered aldehydes and ketones. CpW$(\mathrm{CO})_{3} \mathrm{Na}$ shows kinetic differentiation toward the two functional groups, thereby producing functionalized $\eta^{1-}$ 2,5-dihydro-3-furyl complexes of five-, six-, and sevenmembered rings in moderate yields. The $\eta^{1}$-five-membered heterocycles are demetalated by $\mathrm{Ce}$ (IV) oxidation in $\mathrm{CH}_{2} \mathrm{Cl}_{2} / \mathrm{CH}_{3} \mathrm{OH}$. Although consecutive oxidations of $\eta^{1}$-2,5-dihydro-3-furyl compounds to $\eta^{1}$-2-furyl and $\eta^{1-}$ butenolides are successful, the oxidative demetalation of $\eta^{1}$-2-furyl derivative is not.

\section{Experimental Section}

Unless otherwise noted, all reactions were carried out under nitrogen atmosphere in oven-dried gl assware using standard syringe, cannula, and septa apparatus. Benzene, diethyl ether, tetrahydrofuran, and hexane were dried with sodium benzophenone and distilled before use. Dichloromethane was dried over $\mathrm{CaH}_{2}$ and distilled before use. W(CO) $)_{6}, \mathrm{Re}_{2}(\mathrm{CO})_{10}$, $\mathrm{Cp}_{2} \mathrm{Fe}_{2}(\mathrm{CO})_{4}, \mathrm{BF}_{3} \cdot \mathrm{Et}_{2} \mathrm{O}$, dicyclopentadiene, propargyl alcohol, and sodium were obtained commercially and used without purification. Organic substrates $\mathbf{1 a},{ }^{16} \mathbf{1 b},{ }^{16}$ and $\mathbf{4}-\mathbf{6}^{19}$ were prepared according to literature reports. Syntheses and spectra data of 7-13, 15-23, 25-32, and 36-39 are listed in the supporting information.

Elemental analyses were performed at National Cheng Kung University, Taiwan. Mass data of tungsten and rhenium compounds were reported according to ${ }^{184} \mathrm{~W}$ and ${ }^{187} \mathrm{Re}$ isotopes.

General Procedure for the Intramolecular Cyclization of Propargyl Halides with Aldehydes or Ketones. Annulation of 1-(3-Bromo-1-propynyl)-2-(3-oxopropyl)benzene (1a) with $\mathrm{CpW}(\mathrm{CO})_{3} \mathrm{Na}$. W(CO) 6 (3.75 g, $\left.10.7 \mathrm{mmol}\right)$ and $\mathrm{NaC}_{5} \mathrm{H}_{5}(1.03 \mathrm{~g}, 11.8 \mathrm{mmol})$ were heated in THF $(150 \mathrm{~mL})$ for $84 \mathrm{~h}$. To a THF solution $(5.00 \mathrm{~mL})$ of $\mathbf{l a}(2.60 \mathrm{~g}, 10.7 \mathrm{mmol})$ was added dropwise the above $\mathrm{CpW}(\mathrm{CO})_{3} \mathrm{Na}$ sol ution in three portions at 30-min intervals. Monitoring the solution by silica TLC showed the formation of an $\eta^{1}$-propargyl species (diethyl ether/hexane $=1 / 1, R_{f}=0.82$ ). The solution was stirred for 2 $\mathrm{h}$ at the same temperature before it was evaporated to dryness in vacuo. The $\eta^{1}$-propargyl species was extracted with diethyl ether $(2 \times 20 \mathrm{~mL})$ and filtered under a nitrogen atmosphere. To the ether filtrate (ca. $35 \mathrm{~mL}$ ) was added $\mathrm{BF}_{3} \cdot \mathrm{Et}_{2} \mathrm{O}(0.752$ $\mathrm{g}, 5.30 \mathrm{mmol}$ ) at $-40^{\circ} \mathrm{C}$, and the mixture was slowly warmed to $0^{\circ} \mathrm{C}$ over a period of $4 \mathrm{~h}$. The cyclization was monitored by silica TLC (2a, di ethyl ether/hexane $\left.=1 / 1, R_{f}=0.51\right)$, and the solution was added to a saturated $\mathrm{NaHCO}_{3}$ solution $(10 \mathrm{~mL})$. The organic layer was separated and chromatographed through a short silica column at $23^{\circ} \mathrm{C}$ (diethyl ether/hexane $=1 / 1$ ) to yield $2 \mathrm{2a}(3.07 \mathrm{~g}, 6.10 \mathrm{mmol}, 57 \%)$ as a yellow solid ( $\mathrm{mp} \mathrm{97-99}$ ${ }^{\circ} \mathrm{C}$ dec): IR 2013, $1915 \mathrm{~cm}^{-1}$; ${ }^{1} \mathrm{H}$ NMR $\left(400 \mathrm{MHz} \mathrm{CDCl}_{3}\right) \delta$ $7.73(\mathrm{~d}, \mathrm{~J}=8.9 \mathrm{~Hz}, 1 \mathrm{H}), 7.21-7.08(\mathrm{~m}, 3 \mathrm{H}), 5.62(\mathrm{~s}, 5 \mathrm{H}), 4.73$ $(\mathrm{m}, 1 \mathrm{H}), 4.57(\mathrm{dd}, \mathrm{J}=8.5,4.6 \mathrm{~Hz}, 1 \mathrm{H}), 4.53(\mathrm{dd}, \mathrm{J}=8.5,4.0$ $\mathrm{Hz}, 1 \mathrm{H}), 2.98-2.86(\mathrm{~m}, 2 \mathrm{H}), 2.20(\mathrm{~m}, 1 \mathrm{H}), 1.71(\mathrm{~m}, 1 \mathrm{H}) ;{ }^{13} \mathrm{C}$ NMR (400 MHz, $\left.\mathrm{CDCl}_{3}\right)$ 227.2, 215.9, 214.5, 144.2, 137.2, 133.4, 128.6, 126.5, 126.4, 125.2, 114.9, 91.3, 89.3, 85.2, 31.4, 28.9; MS m/ z $504\left(\mathrm{M}^{+}\right), 448\left(\mathrm{M}^{+}-2 \mathrm{CO}\right)$. Anal. Calcd for $\mathrm{C}_{20} \mathrm{H}_{16} \mathrm{WO}_{4}$ : C, 47.64; $\mathrm{H}, 3.20$. Found: C, 47.70; $\mathrm{H}, 3.35$.

Annulation of la with $\mathrm{NaRe}(\mathrm{CO})_{5} . \mathrm{NaRe}(\mathrm{CO})_{5}(2.80 \mathrm{~g}$, $8.05 \mathrm{mmol})$, 1a $(2.00 \mathrm{~g}, 8.05 \mathrm{mmol})$, and $\mathrm{BF}_{3} \cdot \mathrm{Et}_{2} \mathrm{O}(0.570 \mathrm{~g}$, $4.02 \mathrm{mmol}$ ) afforded $\mathbf{2 b}(1.01 \mathrm{~g}, 2.00 \mathrm{mmol}, 25 \%)$ as a yellow solid (mp 67-69 ${ }^{\circ} \mathrm{C} \mathrm{dec):} \mathrm{IR} \mathrm{2120,} \mathrm{2050,} 2008 \mathrm{~cm}^{-1}$; ${ }^{1} \mathrm{H}$ NMR $\left(400 \mathrm{MHz} \mathrm{CDCl}_{3}\right) \delta 7.48(\mathrm{~d}, \mathrm{~J}=7.4 \mathrm{~Hz}, 1 \mathrm{H}), 7.10-7.25(\mathrm{~m}$, $3 \mathrm{H}), 5.38(\mathrm{dd}, \mathrm{J}=12.0,3.1 \mathrm{~Hz}, 1 \mathrm{H}), 5.29(\mathrm{dd}, \mathrm{J}=12.0,3.1$ $\mathrm{Hz}, 1 \mathrm{H}), 3.06(\mathrm{ddd}, \mathrm{J}=12.0,6.9,5.2 \mathrm{~Hz}, 1 \mathrm{H}), 2.84(\mathrm{ddd}, \mathrm{J}=$ $12.4,7.0,5.6 \mathrm{~Hz}), 2.14(\mathrm{~m}, 1 \mathrm{H}), 1.95(\mathrm{~m}, 1 \mathrm{H}) ;{ }^{13} \mathrm{C}$ NMR $(400$ $\left.\mathrm{MHz}_{1} \mathrm{CDCl}_{3}\right) \delta 212.0,135.4,129.3,128.8,127.3,126.9,126.3$, 107.1, 81.9, 67.6, 30.7, 26.2; MS m/ z $498\left(\mathrm{M}^{+}\right)$. Anal. Calcd for $\mathrm{C}_{17} \mathrm{H}_{11} \mathrm{ReO}_{6}$ : $\mathrm{C}, 41.04 ; \mathrm{H}, 2.23$. Found: $\mathrm{C}, 40.90 ; \mathrm{H}, 2.48$.

Annulation of 7-Bromo-5-heptynal (4) with $\mathrm{CpW}$ (CO) $)_{3} \mathrm{Na}$. CpW $(\mathrm{CO})_{3} \mathrm{Na}(1.90 \mathrm{~g}, 5.30 \mathrm{mmol})$ and $\mathbf{4}(1.00 \mathrm{~g}, 5.29$ mmol) afforded $14(1.54 \mathrm{~g}, 3.50 \mathrm{mmol}, 66 \%)$ as a yellow solid (mp 37-39 $\left.{ }^{\circ} \mathrm{C} \mathrm{dec}\right):$ IR 2018, $1908 \mathrm{~cm}^{-1}$; ${ }^{1} \mathrm{H}$ NMR $(400 \mathrm{MHz}$, $\left.\mathrm{C}_{6} \mathrm{D}_{6}\right) \delta 5.10-5.13(\mathrm{~m}, 1 \mathrm{H} \mathrm{m}), 4.97-5.03(\mathrm{dd}, \mathrm{J}=11.0,4.5 \mathrm{~Hz}$, $1 \mathrm{H}), 4.69-4.72(\mathrm{dd}, \mathrm{J}=11.0,3.4 \mathrm{~Hz}, 1 \mathrm{H}), 4.49(\mathrm{~s}, 5 \mathrm{H}), 2.17-$ $2.22(\mathrm{br} \mathrm{t}, \mathrm{J}=9.5 \mathrm{~Hz}, 1 \mathrm{H}), 1.84-1.97(\mathrm{~m}, 3 \mathrm{H}), 1.68-1.81(\mathrm{~m}$, $1 \mathrm{H}), 1.41-1.51(\mathrm{~m}, 1 \mathrm{H}) ;{ }^{13} \mathrm{C}$ NMR $\left(100 \mathrm{MHz}, \mathrm{CDCl}_{3}\right) \delta 227.2$, 214.9, 214.8, 159.3, 105.1, 94.8, 90.8, 90.5, 31.3, 24.3, 24.5; MS $\mathrm{m} / \mathrm{z} 442\left(\mathrm{M}^{+}\right), 414\left(\mathrm{M}^{+}-\mathrm{CO}\right), 358\left(\mathrm{M}^{+}-3 \mathrm{CO}\right)$. Anal. Calcd for $\mathrm{C}_{15} \mathrm{H}_{14} \mathrm{WO}_{4}$ : C, 40.75; $\mathrm{H}, 3.19$. Found: C, 40.88; $\mathrm{H}, 3.32$.

General Procedure for Demetalations of $\eta^{1}-2,5-D i h y-$ dro-3-furyl Complexes. Synthesis of 3. Compound 2a $(0.20 \mathrm{~g}, 0.40 \mathrm{mmol})$ in $\mathrm{CH}_{2} \mathrm{Cl}_{2} / \mathrm{CH}_{3} \mathrm{OH}(1 / 1,3.0 \mathrm{~mL})$ was cool ed to $-78{ }^{\circ} \mathrm{C}$, and $\mathrm{CO}$ was passed through the solution. To this was added dropwise a solution of $\left(\mathrm{NH}_{4}\right)_{2} \mathrm{Ce}\left(\mathrm{NO}_{3}\right)_{6}(0.66 \mathrm{~g}, 1.20$ mmol) in $5 \mathrm{~mL}$ of $\mathrm{CH}_{3} \mathrm{OH}$ at the same temperature. The solution was warmed to $0{ }^{\circ} \mathrm{C}$ over a period of $2 \mathrm{~h}$. Monitoring the solution by silica TLC plate showed formation of an organic component (diethyl ether/hexane $=1 / 1, R_{f}=0.56$ ). The solution was concentrated and purified by preparative silica TLC to yield 3 as a colorless oil (42 mg, $0.185 \mathrm{mmol}, 46 \%)$ : IR (Nujol) 1700, $1615 \mathrm{~cm}^{-1} ;{ }^{1} \mathrm{H}$ NMR $\left(300 \mathrm{MHz} \mathrm{C}_{6} \mathrm{D}_{6}\right) \delta 9.01$ (d, $\mathrm{J}=7.7 \mathrm{~Hz}, 1 \mathrm{H}), 7.12(\mathrm{t}, \mathrm{J}=7.7 \mathrm{~Hz}, 1 \mathrm{H}), 7.01(\mathrm{t}, \mathrm{J}=7.7 \mathrm{~Hz}$, $1 \mathrm{H}), 6.80(\mathrm{~d}, \mathrm{~J}=7.7 \mathrm{~Hz}, 1 \mathrm{H}), 5.07(\mathrm{dd}, \mathrm{J}=12.6,5.1 \mathrm{~Hz}, 1 \mathrm{H})$, $4.96(\mathrm{dd}, \mathrm{J}=12.6,5.1 \mathrm{~Hz}), 3.28(\mathrm{~s}, 3 \mathrm{H}), 2.51-2.43(\mathrm{~m}, 2 \mathrm{H})$, $2.11-2.02(\mathrm{~m}, 1 \mathrm{H}), 1.82-1.68(\mathrm{~m}, 1 \mathrm{H}) ;{ }^{13} \mathrm{C} N M R(75 \mathrm{MHz}$, $\left.\mathrm{CDCl}_{3}\right) \delta 164.1,148.0,138.8,128.0,130.4,130.2,128.6,125.9$, $120.4,86.5,76.3,51.5,31.2,28.5$; HRMS calcd for $\mathrm{C}_{14} \mathrm{H}_{13} \mathrm{O}_{3}$ 229.0864 , found 229.0861 .

Synthesis of 24. Compound $14(0.13 \mathrm{~g}, 0.298 \mathrm{mmol})$ and $\left(\mathrm{NH}_{4}\right)_{2} \mathrm{Ce}\left(\mathrm{NO}_{3}\right)_{6}(0.50 \mathrm{~g}, 0.90 \mathrm{mmol})$ afforded 24 as a colorless oil (28 mg, $0.167 \mathrm{mmol}, 56 \%$ ): IR (Nujol) 1700, $1615 \mathrm{~cm}^{-1}$; ${ }^{1} \mathrm{H}$ NMR $\left(400 \mathrm{MHz} \mathrm{CDCl}_{3}\right) \delta 5.18-5.13(1 \mathrm{H}, \mathrm{m}), 5.02-4.97(2 \mathrm{H}$, $\mathrm{m}), 3.75(3 \mathrm{H}, \mathrm{s}), 2.72-2.63(1 \mathrm{H}, \mathrm{m}), 2.39-2.32(1 \mathrm{H}, \mathrm{m}), 2.11-$ $1.98(3 \mathrm{H}, \mathrm{m}), 1.50-1.41(1 \mathrm{H}, \mathrm{m}) ;{ }^{13} \mathrm{C} \mathrm{NMR}\left(100 \mathrm{MHz}, \mathrm{CDCl}_{3}\right)$ $\delta$ 164.1, 163.6, 121.3, 92.8, 80.2, 51.3, 30.6, 25.4, 22.4; HRMS calcd for $\mathrm{C}_{9} \mathrm{H}_{12} \mathrm{O}_{3}$ 168.0786, found 168.0783 .

Oxidation of $\mathbf{1 5}$ by $\mathbf{P h}_{3} \mathbf{C B F}_{4}$. To a $\mathrm{CH}_{2} \mathrm{Cl}_{2}(20 \mathrm{~mL})$ solution of $15(1.00 \mathrm{~g}, 1.22 \mathrm{mmol})$ was added $\mathrm{Ph}_{3} \mathrm{CBF}_{4}(0.80 \mathrm{~g}$, $2.62 \mathrm{mmol})$ in $\mathrm{CH}_{2} \mathrm{Cl}_{2}(3 \mathrm{~mL})$ at $0{ }^{\circ} \mathrm{C}$. The solution was stirred 
for $1 \mathrm{~h}$ before quenching with saturated $\mathrm{NaHCO}_{3}$. The organic layer was separated, dried over $\mathrm{MgSO}_{4}$, and evaporated to dryness under vacuum. The residue was eluted through a silica column under nitrogen (diethyl ether/hexane $=1 / 1, R_{f}$ $=0.87)$ to yield $33(0.82 \mathrm{~g}, 1.81 \mathrm{mmol}, 83 \%)$ as a yellow oil: IR 2018, $1924 \mathrm{~cm}^{-1}$; ${ }^{1} \mathrm{H}$ NMR $\left(400 \mathrm{MHz} \mathrm{CDCl}_{3}\right) \delta 6.26(\mathrm{~s}, 1 \mathrm{H})$, $5.52(\mathrm{~s}, 5 \mathrm{H}), 2.56(\mathrm{t}, \mathrm{J}=6.2 \mathrm{~Hz}, 2 \mathrm{H}), 2.30(\mathrm{t}, \mathrm{J}=6.2 \mathrm{~Hz}, 2 \mathrm{H})$, $1.71-1.77(\mathrm{~m}, \mathrm{~J}=6.2 \mathrm{~Hz}, 2 \mathrm{H}), 1.60-1.66(2 \mathrm{H}, \mathrm{m}) ;{ }^{13} \mathrm{C} \mathrm{NMR}$ $\left(100 \mathrm{MHz} \mathrm{CDCl}_{3}\right) \delta 228.5,216.7,158.1,134.7,131.4,119.7$, 92.2, 22.2, 23.6, 23.8, 21.5; MS $454\left(\mathrm{M}^{+}\right), 426\left(\mathrm{M}^{+}-\mathrm{CO}\right), 398$ $\left(\mathrm{M}^{+}-2 \mathrm{CO}\right), 370\left(\mathrm{M}^{+}-3 \mathrm{CO}\right)$. Anal. Calcd for $\mathrm{C}_{16} \mathrm{H}_{14} \mathrm{WO}_{4}$ : C, 42.30; $\mathrm{H}, 3.00$. Found: $\mathrm{C}, 41.98 ; \mathrm{H}, 3.20$.

Oxidation of 33 by m-CPBA. To $33(0.84 \mathrm{~g}, 1.85 \mathrm{mmol})$ in hexane $(5 \mathrm{~mL})$ were added NaOAc $(0.20 \mathrm{~g}, 2.4 \mathrm{mmol})$ and $\mathrm{HOAC}(0.20 \mathrm{~mL}, 3.5 \mathrm{mmol})$. Tothis stirred mixture was added m-CPBA $(0.34 \mathrm{~g}, 1.95 \mathrm{mmol})$ in $\mathrm{CH}_{2} \mathrm{Cl}_{2}(1 \mathrm{~mL})$ at $0{ }^{\circ} \mathrm{C}$. After being stirred for $20 \mathrm{~min}$, the solution was treated with a $\mathrm{Na}_{2}-$ $\mathrm{CO}_{3}$ solution, and the organic layer was extracted with diethyl ether, washed with $\mathrm{NaHCO}_{3}(5 \mathrm{~mL})$, and dried in vacuo. The residue was chromatographed through a silica column (diethyl ether/hexane $=1 / 1)$ to yield $34\left(R_{f}=0.29,0.64 \mathrm{~g}, 1.35 \mathrm{mmol}\right.$, $73 \%$ ) as an orange solid ( $\mathrm{mp} 65-68{ }^{\circ} \mathrm{C} \mathrm{dec}$ ): IR 2021, 1923, $1734 \mathrm{~cm}^{-1}$; ${ }^{1} \mathrm{H}$ NMR $\left(400 \mathrm{MHz} \mathrm{CDCl}_{3}\right): \delta 5.45(\mathrm{~s}, 5 \mathrm{H}), 3.74$ $(\mathrm{s}, 1 \mathrm{H}) 2.23(\mathrm{t}, \mathrm{J}=7.2 \mathrm{~Hz}, 2 \mathrm{H}), 2.03(\mathrm{t}, \mathrm{J}=7.2 \mathrm{~Hz}, 2 \mathrm{H}), 1.76$ $(\mathrm{m}, 2 \mathrm{H}), 1.57(\mathrm{~m}, 2 \mathrm{H}) ;{ }^{13} \mathrm{C}$ NMR $\left(100 \mathrm{MHz} \mathrm{CDCl}_{3}\right) \delta 227.5$, 217.8, 216.6, 188.2, 140.9, 122.8, 92.9, 24.4, 22.7, 22.6, 22.2, 6.8; MS $470\left(\mathrm{M}^{+}\right), 442\left(\mathrm{M}^{+}-\mathrm{CO}\right), 414\left(\mathrm{M}^{+}-2 \mathrm{CO}\right), 386\left(\mathrm{M}^{+}\right.$ - 3CO). Anal. Calcd for $\mathrm{C}_{16} \mathrm{H}_{14} \mathrm{WO}_{5}$ : C, 40.86; $\mathrm{H}, 2.97$. Found: C, 40.88; H, 3.15.
Demetalation of $\mathbf{3 4}$ by $\mathrm{Me}_{3} \mathrm{NO}$. To a solution of $\mathbf{3 4}(0.20$ $\mathrm{g}, 0.43 \mathrm{mmol})$ in $\mathrm{CH}_{2} \mathrm{Cl}_{2}(5 \mathrm{~mL})$ were added anhydrous $\mathrm{Me}_{3}-$ $\mathrm{NO}\left(64 \mathrm{mg}, 0.86 \mathrm{mmol}\right.$ ) and $\mathrm{H}_{2} \mathrm{O}$ (14.4 mg, $0.80 \mathrm{mmol}$ ), and the solution was stirred at $28^{\circ} \mathrm{C}$ for $2 \mathrm{~h}$. The residue was treated with $\mathrm{H}_{2} \mathrm{O}(5 \mathrm{~mL})$, and the organic layer was extracted with diethyl ether, dried in vacuo, and eluted through a silica column (diethyl ether/hexane $=1 / 1)$ to produce $35\left(R_{f}=0.63\right.$, $45 \mathrm{mg}, 0.32 \mathrm{mmol}, 75 \%$ ) as a colorless oil: IR 2057, $1964 \mathrm{~cm}^{-1}$; ${ }^{1} \mathrm{H}$ NMR $\left(400 \mathrm{MHz} \mathrm{CDCl}_{3}\right) \delta 3.10(\mathrm{~m}, \mathrm{~J}=3.7 \mathrm{~Hz}, 2 \mathrm{H}), 2.17$ $(\mathrm{td}, \mathrm{J}=6.0,3.7 \mathrm{~Hz}, 2 \mathrm{H}), 2.00(\mathrm{~m}, \mathrm{~J}=7.9 \mathrm{~Hz}, 2 \mathrm{H}), 1.72(\mathrm{~m}, \mathrm{~J}$ $=6.6,6.0 \mathrm{~Hz}, 2 \mathrm{H}), 1.63(\mathrm{~m}, \mathrm{~J}=7.9,6.6 \mathrm{~Hz}, 2 \mathrm{H}) ;{ }^{13} \mathrm{C} \mathrm{NMR}$ $\left(100 \mathrm{MHz} \mathrm{CDCl}_{3}\right) \delta 176.5,150.5,110.5,36.0,22.5,22.3,22.1$; HRMS calcd for $\mathrm{C}_{8} \mathrm{H}_{10} \mathrm{O}_{2} 138.0680$, found 138.0677 .

Acknowledgment. The authors thank the National Science Council, ROC, for financial support of this work.

Supporting Information Available: Listing of sample preparation, spectral data, and elemental analyses of organic and organometallic compounds including 7-13, 15-23, 2532, and 36-3917 (60 pages). This material is contained in libraries on microfiche, immediately follows this article in the microfilm version of the journal, and can be ordered from the ACS; see any current masthead page for ordering information.

J O952183R 